\section{PRARATCHAPUCCHA: DEVELOPMENT AND SIGNIFICANCE IN BUDDHIST SOCIETY ${ }^{1}$}

\section{Pisit Kobbun $^{2}$}

\begin{abstract}
The research paper aims to study the development and significance of "Praratchapuccha", a Royal inquiry on Buddhist problems, directed at the Buddha himself as well as his disciples. It studies the roles and significance of "Praratchapuccha" during and after the Buddha's era and in early Thai society. The study reveals the development and the transmission of "Praratchapuccha" as well as the significance of "Praratchapuccha" in Buddhist society.
\end{abstract}

"Praratchapuccha" was and is an important tradition in Buddhist society, in the Buddha's time and after the Buddha's time. In the Buddha's era, "Praratchapuccha" served the purpose of encouraging kings to be Buddhist supporters, thereby ensuring a firm establishment of Buddhism. In the postBuddha era, "Praratchapuccha" served the purpose of disseminating and revising the Buddha's teaching as well as creating

\footnotetext{
${ }^{1}$ This research paper is an excerpt from a research entitled "Praratchapuccha: Development and Literary Value" supported by The Thailand Research Fund (TRF). I am grateful to Associate Professor Dr.Suchitra Chongstitvatana for her suggestions and comments.

${ }^{2}$ Lecturer, Department of Eastern Languages and Literature, Faculty of Liberal Arts, Ubon Ratchathani University.
}

a clear and correct understanding about Buddhist doctrines and disciplines.

The tradition of "Praratchapuccha" has been passed down to Thai society and can be seen in the form of Royal Buddhist inquiry, serving the purpose of not only maintaining the Buddhist teachings, but also encouraging monks to actively engage in finding the most comprehensible explanation and answers to the king's questions based on the various Buddhist texts.

\section{Introduction}

Praratchapuccha is a royal inquiry on Buddhist matters proposed to monks in the hope of getting clear answers. HRH Prince Damrong Rajanubhab (1970) stated the characteristics of Praratchapuccha as follows:

The method of Praratchapuccha, as seen in written records, was sometimes done in the presence of monks, sometimes through dictation at the hands of royal pundits. Then the Praratchapuccha was presented to the Supreme Patriarch... The Praratchapuccha tradition is believed to be a tradition carried on in countries that have been Buddhist countries since ancient times. In other countries no Praratchapuccha manuscripts have been found, except for the Milindapañha scripture, in which King Milinda interrogated Nāgasena in India. Perhaps succeeding kings, touched by Buddhism, liked the style of King Milinda and so Praratchapuccha became a tradition. (Damrong Raganubhab 1970: Introduction)

In this study I aim to examine Praratchapuccha as a tradition which has 
been carried on since the Buddha's time until its appearance in Thai society by examining Praratchapuccha with regard to the traditional development of Buddhist society, its continued existence and its importance in the context of different periods and social conditions.

\section{Praratchapuccha in the Buddha's time}

In the Buddha's time, there existed many beliefs in society. Evidence from the Tipitaka displays society at that time as group of people in search of the path to liberation from suffering. For example, Brahmajālas Sutta, Dīgha Nikāya (Walshe 1987: 73-75) sets out, in sixty-two divisions, always going out from various forms of ancient views of liberation while Pathamanānātthiya Sutta, Udāna (Ireland 1997: 81-84) showed the disputation over those beliefs. There were philosophical and religious debates. The Buddha himself, after declaring Buddhism, had to deliver sermons to many sect leaders.

Among the variety of beliefs in the Buddha's time, there were the sects of six teachers ${ }^{3}$ that were popular and played an important role in the Buddha's time. In other words, there were many believers, and importantly, there were kings and townsfolk who formerly had had faith in these cults before converting to Buddhism. For instance, King Bimbisāra and the Rājagaha people believed in the three Jatila brothers (matted-hair ascetics). King Pasenadi and the people of Kosala believed in Brahmans and Nigantha a (ascetic in Jainism).

\footnotetext{
${ }^{3}$ The six teachers are Purāna-Kassapa, Makkhali-Gosā, Ajita-Kesakambala, PakudhaKaccāyana, Sañjaya-Belațthiputta, NigaṇthaNātaputta
}

After the Buddha had attained supreme knowledge, he preached firstly to the five wandering ascetics (1995: 263-268), then to Yasa and friends, until there were 60 arahat $^{4}$ disciples. The Buddha then sent these disciples to spread Buddhism to different lands (Strong 2002: 85-88). The Buddha himself went to Rājagaha Magadha to preach King Bimbisāra. $\mathrm{He}$ had promised that the King would be the first person to hear his sermon if he had attained supreme knowledge. Moreover, it is likely that the Buddha saw that King Bimbisāra was the ruler of a big town. So teaching King Bimbisāra, and leading him to have faith in Buddhism would lead to an increase in the number of Buddhist believers and the firm establishment of Buddhism.

Formerly King Bimbisāra and the Rajjagaha townsfolk had revered the three Jatila brothers. Then, Lord Buddha journeyed to Magadha and started to teach Uruvelakassapa, his two brothers and 1,000 servants to abandon the former faith and turn to Buddhism, resulting in their all attaining arahatship and becoming his disciples.

When the Buddha and King Bimbisāra first met, according to the Tipitaka, King Bimbisāra heard the message that the Buddha had displayed great intelligence in attaining enlightenment on his own, as well as teaching doctrine to humans, brahmā and angels, and had journeyed to Rājagaha. Therefore, King Bimbisāra went with the householders of Magadha to pay homage to the Buddha. $\mathrm{He}$ and the householders wondered why Uruvelakassapa

\footnotetext{
${ }^{4}$ Arahat is "the term denotes a person who had gained insight into the true nature of things. In the Buddhist movement, the Buddha was the first arahant."
} 
and his brothers and disciples had given up fire-worship and had turned to a faith in the Buddha. To this, Uruvelakassapa replied that having listened to the Buddha's sermons and immediately grasping Buddhist doctrine, which was the way to peace, he had abandoned fire-worship which was useless, and had professed himself the Buddha's disciple. On this occasion the Buddha preached to King Bimbisāra and the Brahman householders of the Magadha, delivering gradual instructions (anupubbikathā) namely: (1) dāna-kathāa, sermon on giving, (2) sīla-kath $\bar{a}$, sermon on good conduct, (3) sagga-kath $\bar{a}$, sermon on heaven, and (4) magga-kathā, sermon on the path to Nibbana; he proclaimed the danger, elimination and impurity of sense desire and the benefit of lack of desire. Then he delivered a precept that was the core of Buddhism, which is the Four Noble Truths: suffering, its origin, its cessation and the path to liberation. The entire audience became enlightened and professed themselves to be Buddhist laymen (Horner 1993: 52-55). King Bimbisāra attained sotāpattiphala (the fruition of stream-entry), became a sotāpanna (stream enterer), and professed himself to be a Buddhist. King Bimbisāra thought of an appropriate dwelling place for the Buddha and his disciples, so he offered the Veluvana (bamboo grove), for the Buddha and the latter accepted it. This is considered the first temple in Buddhist history.

After converting to Buddhism, King Bimbisāra maintained Buddhism in all aspects, resulting in a large number of Buddhist believers in Magadha. The Tipitaka also shows that King Bimbisāra repeatedly had Praratchapuccha with the Buddha. The tradition of having Praratchapuccha was thus formed and became an enduring practice in Buddhist society.

King Ajātasattu also had Praratchapuccha with the Buddha repeatedly. One very important occasion was the first encounter. That Praratchapuccha occasion made Buddhism a more widely accepted religion because it confirmed the prophet's teaching. According to the Sāmaññaphala Sutta and Dīgha Nikāya (Walshe 1987: 91-109) King Ajātasattu mentioned in the Praratchapuccha that all careers that men pursued to earn their living at that time allowed them to easily provide for themselves and their people, as well as to make merit to the Brahman ascetics for their physical and psychological contentment. Then, was the Buddha able to explain the benefits of being a Buddhist recluse as a state attained through dhamma practice? The Buddha asked King Ajātasattu whether he had asked other priests and contemplatives this question; the latter replied that he had asked all six teachers but no one could give a satisfactory answer, so the Buddha taught him about the fruits of the contemplative life with counter-questions:

1. If a person who used to be a slave or labourer of King Ajātasattu's had gone into the monkhood and had behaved decently, would the king demand that he return to his former status as a slave or labourer? King Ajātasattu said he would not but would show reverence and offer the four requisites and protection. The Buddha concluded that these were the rewards of monkhood as seen at the current time.

2. If a person who used to be a farmer and a householder of King Ajātasattu's had gone into the monkhood and behaved decently, would the king demand that he 
return to his former householder status as a farmer? King Ajātasattu said the same as for the previous question, that these were the rewards of monkhood as seen at the current time.

3. Householders or their descendants, having listened to the Buddhist doctrines and then having entered the monkhood, practised good conduct by leading a holy life, kept themselves morally pure, had self-control of the sense-faculties, did not allow unwholesome thoughts, had awareness of the present moment and contentment, were content with the four requisites as received, journeyed into the forest to meditate, relinquished those defilements that are called the five hindrances, and attained the four higher ones-states of serene contemplation attained by meditation. These were the fruits of monkhood as seen at the time.

Then, after humbling oneself to be able to attain the eightfold level of knowledge, one reached the perfect knowledge that the body naturally degenerates. Through body consciousness one gained insight into the true nature of things and was able to create another body from this body and show extra sensory powers such as the ability to walk on water, disappear, have clairaudience, read minds, recollect past lives, know how other lives began and ended through clairvoyance and know how to get rid of the defilements that had been accumulated in the core of one's being.

After the Buddha had finished his sermon, a strong faith overcome King Ajātasattu and he made a vow to become a devout layman, taking the Ratanattaya as a refuge for his lifetime and pleaded pardon for killing his father (King Bimbisāra), which the Buddha granted.
King Pasenadi was the king of Kosala. He was an important patron of Buddhism in the Buddha's time. Two years after the Buddha had started preaching in Magadha, he went to Kosala. At first King Pasenadi followed the Jainism religion and he believed in the Brahman ascetic practice of animal sacrifice. At one time King Pasenadi performed a colossal ceremony of sacrifice, for which seven hundred of each kind of animal was prepared, because he had heard a puzzling loud noise in a dream. Then a Brahman ascetic had found a clue to this puzzle and had suggested he make sacrifice. Mallikā, his wife, objected, so a great massacre was avoided, and she was the person who persuaded King Pasenadi to turn to Buddhism.

In the Dahara Sutta, Samyutta Nikāya (Davids 1971: 93-96) King Pasenadi met the Buddha and experienced Praratchapuccha on the Buddha's enlightenment, asking if the Buddha could ensure that he would perfectly attain supreme knowledge. The Buddha said he could. King Pasenadi continued by stating that other ascetics such as the other six teachers had not ensured that they were self-awakened to this supreme knowledge, even though they were well advanced in years. The Buddha was still young and a newly ordained monk. Why, then, did the Buddha have such confidence? The Buddha answered that there are four things that should not be disdained as lowly;

1. A young king should not be disdained because he could decree momentous punishment.

2. A small snake should not be disdained for its size because it is poisonous and deadly. 
3. Fire should not be disdained because it can grow into a big fire with great destructive power to burn things down.

4. A young monk should not be disdained because he is a holy man. Anyone who harms a monk will receive severe punishment and will be perished. ${ }^{5}$

After the Buddha had finished his sermon, King Pasenadi was awed and made a vow to be a devout layman in support of Buddhism for his lifetime. Afterwards, when King Pasenadi turned to Buddhism, his Praratchapuccha appeared in the Tipitaka. Furthermore, he constantly inquired about dhamma matters from the Buddha and Buddhist disciples.

Praratchapuccha was developed from the questions raised by kings who knew about the Buddha's enlightenment in order to examine the Buddha's knowledge when they met. The Buddha's answers and his teachings induced clear and correct understanding about Buddhism and eliminated all doubt in the Buddha and his teachings. Thus, in the Buddha's time, Praratchapuccha was considered highly important. The kings' questions and the Buddha's answers also induced faith in Buddhism, thus causing Buddhism, which was a new belief at that time, to become stable, and increase its number of followers, mainly because Buddhism had received patronage from the kings. Therefore, all the monks could learn the doctrine and spread the Buddha's teaching without difficulty.

\footnotetext{
${ }^{5}$ The Kosala Samyutta in Samyutta Nikāya reveals the close relationship between King Pasenadi and the Buddha through various dialogues.
}

\section{Praratchapuccha after the Buddha's time}

After the Buddha's time, Buddhism remained popular. Nevertheless, as time progressed, the Buddha's teaching faded. Also, monks were lackadaisical in observing discipline and did not study the Buddha's teaching deeply enough. Because of this and the changing the social conditions, plausible doubt on the Buddha's teaching and there was uncertainty as to what the right teaching was. Thus, Praratchapuccha during this time showed the characteristics of the purposes of studying Doctrine and Discipline and eliminating doubt in the Doctrine and the Discipline, through questioning and answering with the primary intention for bringing about clear understanding. The Praratchapuccha of the kings after the Buddha's time also led to maintaining Buddhism in stable continuity through correct dhamma teaching. This paper focuses on the Praratchapuccha of two kings, King Asoka and King Milinda because of their interest in the Buddha's teaching and dedication in supporting Buddhism.

King Asoka was a highly significant king with regard to Buddhism because of his patronage and dedication in spreading Buddhism. King Asoka's former belief was in Brahmanism. After the war in Kalinga, when many people lost their lives, King Asoka was deeply grieved. Subsequently, he met Nigrodha sāmanera ${ }^{6}$,

\footnotetext{
${ }^{6}$ Nigrodha sāmanera was King Asoka's own nephew, the son of his brother Sumana. When Asoka had Sumana put to death so that he could assume power, Sumana's wife had taken refuge in a Caṇ̣̂āla village where she gave birth to a son who was given the name of Nigrodha. The Arhat Mahāvarun foresaw the
} 
and he admired his monastic duty that was discreet and peaceful, so he had Praratchapuccha with the Nigrodha sāmanera and asked the Nigrodha sāmanera to teach dhamma to him. Nigrodha sāmanera delivered a sermon on heedfulness in the Path of Dhamma (Dhammapada), about prudence being the way to life and imprudence to ruin. (Strong 1989: 76). King Asoka's Praratchapuccha and Nigrodha sāmanera's answers gave King Asoka strong faith in Buddhism and thereafter he provided continuous support for the Buddhist monastery.

After King Asoka had become a Buddhist, he noticed there were many adherents of heretical teachers who disguised themselves as monks to obtain offerings and that real monks would not perform recitation with these false monks. King Asoka decided to purify irreligious monks who were staining Buddhism and asked a councilor to suppress any disputation. The councilor misinterpreted the king's words as an order to kill any monks who would not conform to correct the recitation, so he killed a large number of these monks. Afterwards King Asoka was worried about whether he would be doomed to karmic punishment, so he had Praratchapuccha with Moggaliputta-Tissa on the question of sin, as the King upon whom the sin would fall. Moggaliputta-Tissa replied that if King Asoka had had no premeditation then he was free of guilt. (Strong 1989: 22-23). Moggaliputta-Tissa also recommended that King Asoka hold a Buddhist council for the revision of the

child's future and had induced him to enter the Buddhist Order; the very day of his ordination, Nigrodha attained arahatship. He was only seven years old when Asoka saw him from his window and summoned to his place. (Lamotte 1988: 250) doctrine as an offering to the Buddha with the aim of purifying the religion, so King Asoka granted the Third Council in Buddhist history.

From King Asoka's legend and Praratchapuccha with the monk, it is evident that Praratchapuccha inspired faith in Buddhism, which led to royal patronage and the maintenance of stability and the eventual purification of the doctrine.

In the Milindapañha ${ }^{7}$ there is a story of King Milinda who had Praratchapuccha with Nāgasena. King Milinda was the Bactrian Greek king also known as Menander, a powerful king who ruled over an extensive portion of North-West India (Lamotte 1988: 418-420). The content of the Praratchapuccha in the Milindapañha shows that King Milinda had an excellent knowledge of Buddhism. Nāgasena used literary techniques that facilitated insight into Buddhist dhamma through the elaborate, sagacious and clear use of imagery. The foremost virtue of Milindapañha is that it can make the Buddha's teachings which are abstract and difficult to comprehend accessible through vivid illustration with beautiful language.

The first Praratchapuccha upon meeting Nāgasena well illustrates the wit of the two. King Milinda inquired about formmind (Rūpa-Nāma) and Nāgasena replied with clarity that it takes both the form and the mind to make a person with a name, but ultimately, no person with a specific

\footnotetext{
${ }^{7}$ Milindapañha was written around 500 B.E. It is an outstanding Buddhist literary work widely known among those who profess or are engaged in Buddhist studies. It is called Pakaranavisesa, a literary work created to explain the Buddha's teaching drawings on the content of the Tipitiaka.
} 
name exists. King Milinda approved Nāgasena's ability in explaining dhamma. (Davids 1969: 40-45) The first Praratchapuccha encouraged both King Milinda and Nāgasena to continue to have question-answer and exchange ideas on Buddhist doctrine as knowledgeable sages. Thanks to the dialogue technique of the two, Buddhist dhamma was verified, attested and the misunderstanding thereof rectified and true understanding brought to light. For example, in the Mendakapañha when there are double-pointed problems puzzling question forms, different statements on the same topic that seem to disagree are raised as follows:

Venerable Nāgasena, it has been said by the Blessed One: "The Tathagata, O brethren, the arahat, the Buddha supreme, is the discoverer of a way that was unknown."

But on the other hand, he said: "Now I perceive, O brethren, the ancient way, the ancient path, along which the previous Buddhas walked."

If, Nāgasena, the Tathagata is the discoverer of a way not previously known, then it must be wrong that it was an ancient way that he perceived, an ancient path along which previous the Buddhas walked. But if the way he perceived were an ancient way, then the statement that it was unknown must be wrong. This too is a double-edged problem, now put to you, which you have to solve. (Davids 1969: 13-16)

Nāgasena replied that this question seemed to be inconsistent but both questions were accurate. The former Buddhas had Parinibbāna and since nobody taught the Buddha's teaching, the essence of Buddhadhamma completely disappeared. When the Buddha Sakkamuni came into existence, he discovered the same path of the former Buddhas. Nāgasena revealed his answer by using metaphors as follows:

It was as if some man or other finds a thing that has been lost, and the people use the phrase: "He brought it back to life."

And it is as if a man was to clear away the jungle, and set free a piece of land, and the people use the phrase: "That is his land." But that land is his. It is because he has brought the land into use that he is called the owner of the land. Just so, O king, did the Tathagata, having gained a thorough knowledge of it through the eyes of his wisdom, bring it back to life and make it passable again, a way that was already there, then broken up, crumbled away and gone to ruin, closed in, no longer passable and lost to view. And therefore it is that he said: "The Tathagata, O brethren, the arahat, the Buddha supreme, is the discoverer of a way that was unknown." (Davids 1969: 15-16)

Praratchapuccha in Milindapañha is discernable in that the questions are wellordered. The work begins with simple single-message questions and the complexity of the questions gradually develops. Concerning the answers, the explanations are detailed, relying on repetition both in terms of content and language structure as illustrated by the given examples. There is also a 
remarkable order of the steps and methods in asking questions and giving answers to a Buddhist issue under discussion. Moreover, in the explanation, other devices are employed to make the problematic issue clear, yielding literary beauty to the work.

The Milindapañha is proof of the Praratchapuccha tradition, it is important to Buddhist society for the way it helps rectify Buddhist doctrine and making it lucid with no more doubt.

\section{Praratchapuccha in Thai society}

In Thai society there has been a recorded form of Praratchapuccha from the Ayudhya period to the early Ratanakosin period, which shows the importance of Praratchapuccha as a tradition of Thai kings $^{8}$ whose obligation is to be concerned about Buddhism. The origin of Praratchapuccha is from the king's daily routine. In most cases, the first portion of Praratchapuccha is the query on account of what the king had heard from a monk's sermon that had made him wonder, so he had an inquiring letter sent. Praratchapuccha in Thai society had a special characteristic which was different from in the past-the style was rather more formal. There was a scribe who recorded Praratchapuccha. Then he handed it to a monk for the latter to answer in written form.

The Praratchapuccha of King Rama I revealed his true concern for Buddhism in his attempt to purify and rectify the Doctrine and the Discipline. Also, his

${ }^{8}$ The duty of kings (พระราชานุกิจ) to educate about Buddhism can be found in the "The

Code of Three Great Seals" (กฎหมายตราสามดวง).
Praratchapuccha also obviously illustrates his deep knowledge of Buddhism, from the way he had Praratchapuccha on 39 occasions with the substance covering the teaching, the Doctrine and the Discipline, and Buddhism-related activities. He had a definite objective to recover lost Buddhist knowledge. For example, he was sceptical of some messages preached by a monk. It was stated in the Sōtappamālinī ${ }^{-9}$ that a fish swam after an argosy to listen to sermons from a monk and a cockatoo practised self-meditation and both were reincarnated as humans and achieved the fruit of following the path of truth as a reward for just listening to sermons and selfmeditation. He thought that to achieve the fruit of following the path of truth, one must give alms, accumulate virtues for a long time, in the way that the Buddha fulfilled Perfection for a long time before attaining enlightenment. He thought that there should be further explanation and mentioned,

"Could the monks please confer among themselves as to what is right? Please teach all monks to give sermons in the royal court or outside the royal court, expounding the doctrine lucidly and elaborately, not incompletely as was the case, because less intellectual people will then hold wrong beliefs and misunderstanding, which would be really futile." (The Collection of Praratchapuccha 1970: 105)

This example obviously illustrates his proficiency in Buddhism, for he had analyzed the monk's teaching, and thus

\footnotetext{
${ }^{9}$ Buddhist scripture contains Buddhist doctrines such as merit-making, hearing a sermon, and their benefits.
} 
made him pose Praratchapuccha again, to which the monk replied that it was just a rough idea in that sermon. Actually it was as King Rama I had stated, to achieve the fruit of following the path of truth, one has to fulfill Perfection for a long time. What he said reflects his concerns. Seeing that others probably had misunderstandings about this matter, he posed Praratchapuccha for the monk to give an answer in order to explain more, that the correct understanding of the teaching may be possible for the listener's benefits.

Praratchapuccha displays an interest in religious matters both for the doctrine and other matters relevant to Buddhism. The subjects of Praratchapuccha were about traditions, beliefs, and practices that would yield benefit and blessings to the land in general. For example, Praratchapuccha was made on the restoration of Buddhist sanctuaries, the construction of pagodas or major Buddha images, practices that conformed to Buddhist precepts in royal Buddhist ceremonies in order to settle on the right practices and create unity in society, with the king as the presiding figure and centre. For instance, during the reign of King Rama II (1767-1824) there was an epidemic, of cholera resulting in large casualties. The king had Praratchapuccha on making merit and the monks recommended a grand occasion of making merit, that is, the revival of the Full-Moon day rituals (Visākhapūja). Consequently, the king had merit-making held on the occasion of the Full-Moon day to disperse all danger from the land and also to give moral support to the people.

Praratchapuccha is, moreover, an important royal ministry. Apart from the purpose of understanding Buddhist doctrine, having Praratchapuccha is also for inspecting and examining the monks' knowledge of Buddhism. Praratchapuccha in Thai society made the monks seek accurate answers to present to the king. Each Praratchapuccha may be answered by only one monk or a committee of monks, with reference to a variety of Buddhist scriptures, with the primary aim of maintaining the Buddha's teaching. The intention of the king for Praratchapuccha was not to allow the teaching to have any slight differences. In the Praratchapuccha of King Rama III (1788-1851) the King set the manner for answering questions that monks had to follow,

"Each monk must contemplate the Pāli Canon and then write a piece of discussion in a notebook, indicating the cited scripture, for submission.... but the royal command was that it was prohibited for monks to confer among themselves but to let only what were their ideas be the answer." (The Collection of Praratchapuccha 1970: 215)

Praratchapuccha contains a wide variety of content and substance about Buddhist matters that are;

(1) Buddhadhamma that mainly explains the meaning of Buddhist doctrines, the Buddha's sayings and the Buddhist texts. The Buddhadhamma in Praratchapuccha contains worldly buddhadhamma; the ways of creating pleasure and satisfaction and, profound transcendent buddhadhamma.

(2) The history of former Buddha and the Bodhisatta. The content presents fulfillment of the perfection of the Buddha to enlightenment.

(3) A Buddhist tradition such as the ordination and the ways of merit-making. Praratchapuccha created understanding in 
Buddhist tradition, culture and doctrines to be the main practices.

(4) The Buddhist discipline for monks. Since the Buddhist monks took an active part in Buddhist society, these monks should strictly keep the rule of disciplines, practice meditation to gain insight and preach Buddhist knowledge to people so as to be used in their daily life.

The contents in Praratchapuccha reveal the kings' interest in Buddhism in order to create clear understanding about Buddhism.

\section{The development and significance of Praratchapuccha}

The development of Praratchapuccha in the dimension of historical time mentioned above shows the changing process that has occurred consistently through time. The development and existence of the Praratchapuccha tradition obviously illustrates the functional significance of this tradition. However, the development of Praratchapuccha was not only due to the time dimension but was also due to the function of this tradition in different Buddhist social and cultural contexts. Different ages or periods have Praratchapuccha of different characteristics and significance.

Historically, it is evident that Praratchapuccha is a tradition that has existed along the unbroken course of Buddhist existence. As the Praratchapuccha tradition came into existence Buddhism was firmly established. Therefore, the kings' Praratchapuccha and the Buddha's and his disciples' discourses on the doctrine were important factors in Buddhism's stability. With the kings as the important instrument, both the Buddha and the disciples were dedicated to explaining Buddhist philosophy to the kings repeatedly, resulting in the king's strong faith in Buddhism. The faith of the leader thus had an impact on that of the population. The leader of the society's conversion to Buddhism thus had a great impact on Buddhism's support, which was a way of giving monks status in society and time for spiritual practice. For instance, King Bimbisāra, as previously mentioned, offered Veluvana to the Buddha; King Pasenadi invited monks to receive food offerings; or King Ajātasattu gave patronage to the first council of the Tipitaka. These clearly illustrate how Praratchapuccha and explanations of the doctrine brought faith and led to the support of the Buddhist monastic orders, while the duty of Buddhism was to enlighten society.

Praratchapuccha had a varied content. On many occasions, Praratchapuccha posed by the kings to monks shows that besides giving answers to teach Buddhist philosophy and give Buddhist knowledge, it was also to remind the kings to have judgment and mindfulness. For example, in Jațila Sutta, Samyutta Nikāya (Davids 1971: 104-106) the Buddha reminded King Pasenadi not to be entrapped by external appearance. In the Jatila Sutta, King Pasenadi showed reverence to nonBuddhist ascetics, and then told the Buddha that those ascetics were enlightened ones. The Buddha inquired how he knew that these were enlightened arahats. Then he admonished the inquirers that in order to know who keeps precepts one has to be around that person for a considerable period of time, knowing whether the person is pure is achieved through speaking, knowing whether one is intellectual is previewed through conversation and knowing whether one has strong spirit is discovered when falling into dangerous situations. 
Thus, the role of Praratchapuccha is not only for teaching Buddhist philosophy but is the way monks' explanations also serve to remind and admonish kings on state affairs management. Therefore, Praratchapuccha reflects the interdependence between the Buddhist monastic order and kingship.

After the Buddha left his mortal body, disciples in the later period were probably lax in the Discipline, which was an important factor in the fading of Buddhist knowledge, twisted understanding, as well as false monks intermingling in Buddhist society. When the kings noticed these anomalies in society, they thought these might lead to the end of Buddhism. Praratchapuccha in the post-Buddha time existed for the mutual support between Buddhist monastic orders and earthly kingdoms but another important function was the verification of the doctrine and the discipline, rectifying the Buddha's teaching to be as pure as when the Buddha was alive. King Asoka is an example of a king who was concerned about Buddhism. The Praratchapuccha he posed to monks was for the purification of Buddhism. In his time there were many false monks, whom he tried to deal with. When unintended violence broke out, he was worried about having sinned, so his Praratchapuccha yielded the opportunity for monks to give answers, suggesting the course of action to relieve anxiety, that is, to revise the dharma. Therefore, the motive of Praratchapuccha led to the systematic revision of the Doctrine and the Discipline, so that the Doctrine and the Discipline might return to purity and be correct as it had been in the past.

It is the same as the case of King Milinda's Praratchapuccha posed to
Nāgasena. One reason was the attempt to purify the Buddhist doctrine to be correct because as time progressed the Buddha's teaching might be interpreted incorrectly.

The Praratchapuccha tradition has continued in Thai society. Buddhism has been carried on steadfastly in Thai society because the study of the Dhammavinaya has been encouraged in both monks and laymen. The king's Praratchapuccha has been considered an obligatory tradition; every Thai king has to discuss Buddhist principles with monks as appears from the King's Daily Routine, in which there is a set time for the king to listen to sermons and converse on spiritual matters with monks. However, the relationship between the Buddhist monastic order and the earthly kingdom in Thai society is apparent in its close interdependence. Frequently kings have had Praratchapuccha with monks on state matters. For example, King Narai (The Collection of Praratchapuccha 1970: 3-4) inquired whether the gossip about his indulgence to westerners was appropriate. Brahmamunī bhikkhu replied that gossiping was not a right thing and he admonished King Narai that if he did not hear that gossip himself, he should be strong and not trust other people too easily.

The importance of Praratchapuccha went hand in hand with the development of Thai society. Praratchapuccha reflects the flourishing of Buddhism. The kings paid attention to the purification of Buddhist knowledge for correction. Monks tried to search for truth from various scriptures to give answers explaining knowledge broadly, until Praratchapuccha became a tradition that the kings had to practice. In a way, it reflects the concern in Buddhism and examines the monks' knowledge; it is 
a duty to be performed for the continuation of Buddhism.

This interaction between the kings and a monk or a group of monks in Praratchapuccha reflects the importance of discussing and studying Buddhist principles. To regard Thai kings as the questioners on Buddhist principles and Buddhist-related activities, their questioning may spring from excellent knowledge of Buddhism. Each question arises from analysis and observations on Buddhist accounts. With regard to the monks, as the explaining party, they would attempt a search for knowledge from a diversity of Buddhist scriptures to clarify questions on spiritual matters. Thus, the interaction between the kings and monks in Praratchapuccha is for the purpose of generating knowledge and understanding with lucidity and congruity with Buddhist accounts which is considered a deed for the preservation and continuation of the Buddha's teaching.

\section{Conclusion}

Praratchapuccha has had a great significance in Buddhist society and culture from the Buddha's time through the post-Buddha time. Praratchapuccha has seen developing importance along the line of the development and the flourishing of Buddhism, in the same way the king's status as patron, has affected the establishment, upholding, and spreading Buddhist teaching in an accurate and pervasive manner.

Apparently, in the Buddha's time, his establishing and spreading of the religion in communities that full of diversity of belief were the consequences of deliberately talking about the religion to the kings. The kings' conversation to
Buddhism undoubtedly strengthened Buddhism, so Praratchapuccha has had significance in the Buddhist establishment. Through the king's faith, Praratchapuccha in the Buddha's time existed for spreading and teaching the principles to a wider audience that the Buddha had obtained through attaining supreme wisdom.

After Buddhism had established firmly, the development and significance of Praratchapuccha, thereafter, also had the important role of clarifying the Doctrine and the Discipline and confirming the right teaching of the Buddha. After the Buddha passed away, these were important to the continuance of Buddhist teaching without any deviation. Moreover, the substance of Praratchapuccha was also relevant to the Norm-Discipline, the Doctrine, and the essence relevant to Buddhist life in terms of tradition, religious rituals and other practices belonging to Buddhist principles. Thus, there is a parallel between the development of Praratchapuccha and social evolution.

Therefore, it is valid to state that Praratchapuccha, as an important Buddhist tradition, had unbroken development, which occurred in parallel with the importance, role and function of Praratchapuccha in the social and cultural contexts of each period, such as establishing Buddhism, building faith and handling wrong views to make way for teaching Buddhist principles. It was also significant in the spread, inspection and purification of the Dhammavinaya. The development that has transpired with the presence of the functional importance of Praratchapuccha has led to the mutual support and interrelationship between the Buddhist monastic order and the earthly Kingdom, which owe each other a commitment. 


\section{Reference}

Arahat, Arahant. January 6, 2011. $<$ http://www.palikanon.com/ english/pali_names/ay/arahat.htm>.

Damrong Rajanubhab, HRH Prince. 1970. "Introduction." The Collection of Praratchapuccha. Bangkok: Business Organization of the Office of the Welfare Promotion Commission for Teachers and Education Personne.

Davids, T.W. Rhys (trans.). 1971. The Book of the Kindred Sayings (Samyutta Nikāya) Part I. London: Pali Text Society.

Davids, T.W. Rhys (trans.). 1969. The Question of King Milinda. Delhi: Motilal: Banarsidass.

Ireland, John D. (trans.). 1997. The Udāna and Itivuttaka: Two Classics from the Pāli Canon. Kandy, Sri Lanka: Buddhist Publication Society.

Lamotte, Etienne. 1988. History of Indian Buddhism from the Origins to the Śaka Era. Louvain-la-Neuve:

Universitecatholique de Louvain, Institut Orientaliste.

Ñāṇamoḹ Bhikkhu and Bodhi Bhikkhu (trans). 1995. The Middle Length Discourse of the Buddha (Majjhima Nikāya). Kandy Srilanka: Buddhist Publication Society, 1995.

Strong, John S. 1989. The Legend of King Aśoka. Princeton: Princeton University Press.
Srong, John. 2002. The Experience of Buddhism. Wadsworth/Thomson Learning.

The Collection of Praratchapuccha. 1970. Bangkok: Business Organization of the Office of the Welfare Promotion Commission for Teachers and Education Personne.

Walshe, Maurice (trans.). 1987. Thus Have I Heard: The Long Discourses of the Buddha (Dīgha Nikāya). London: Wisdom Publication. 


\section{Appendix}
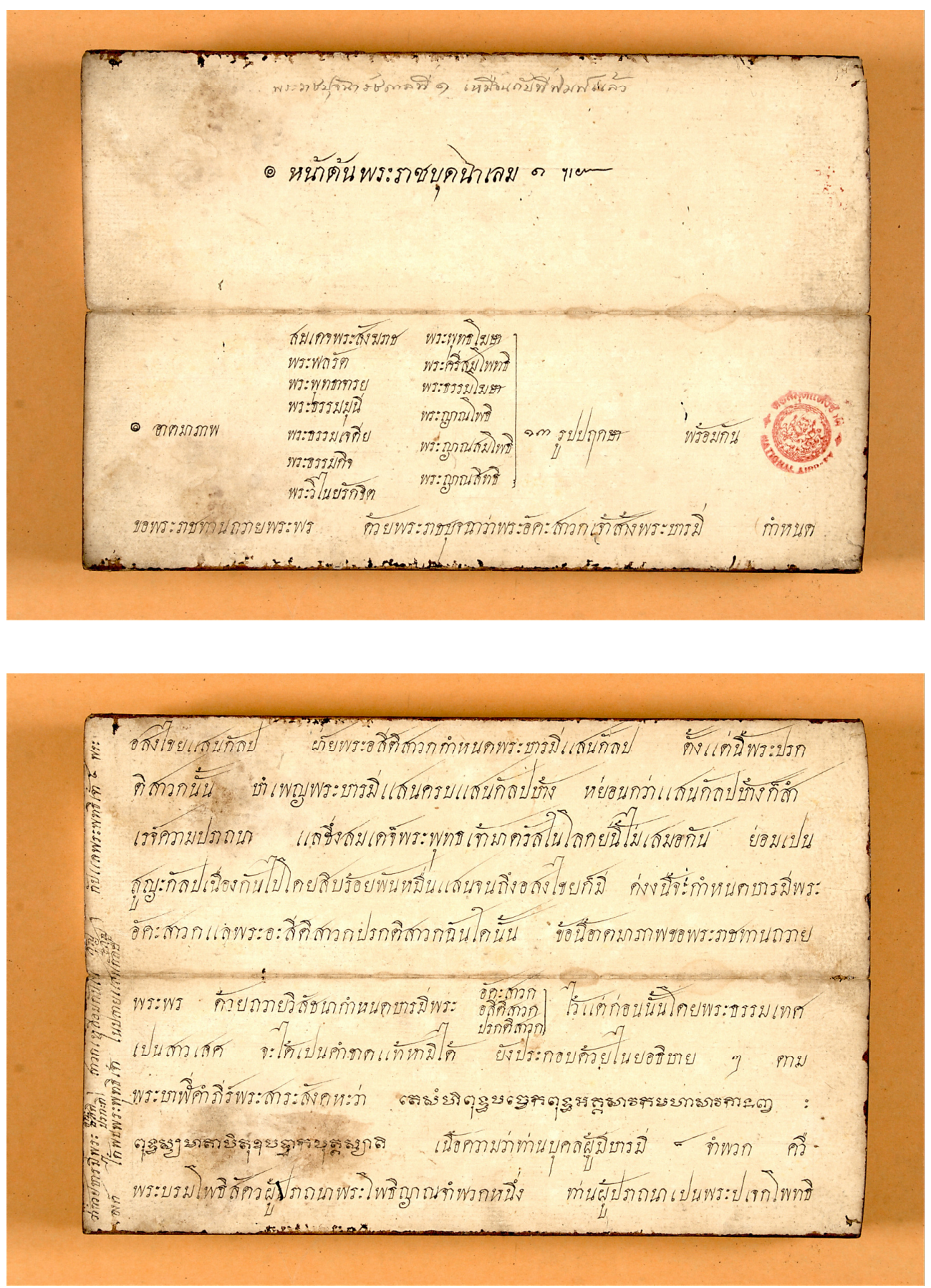

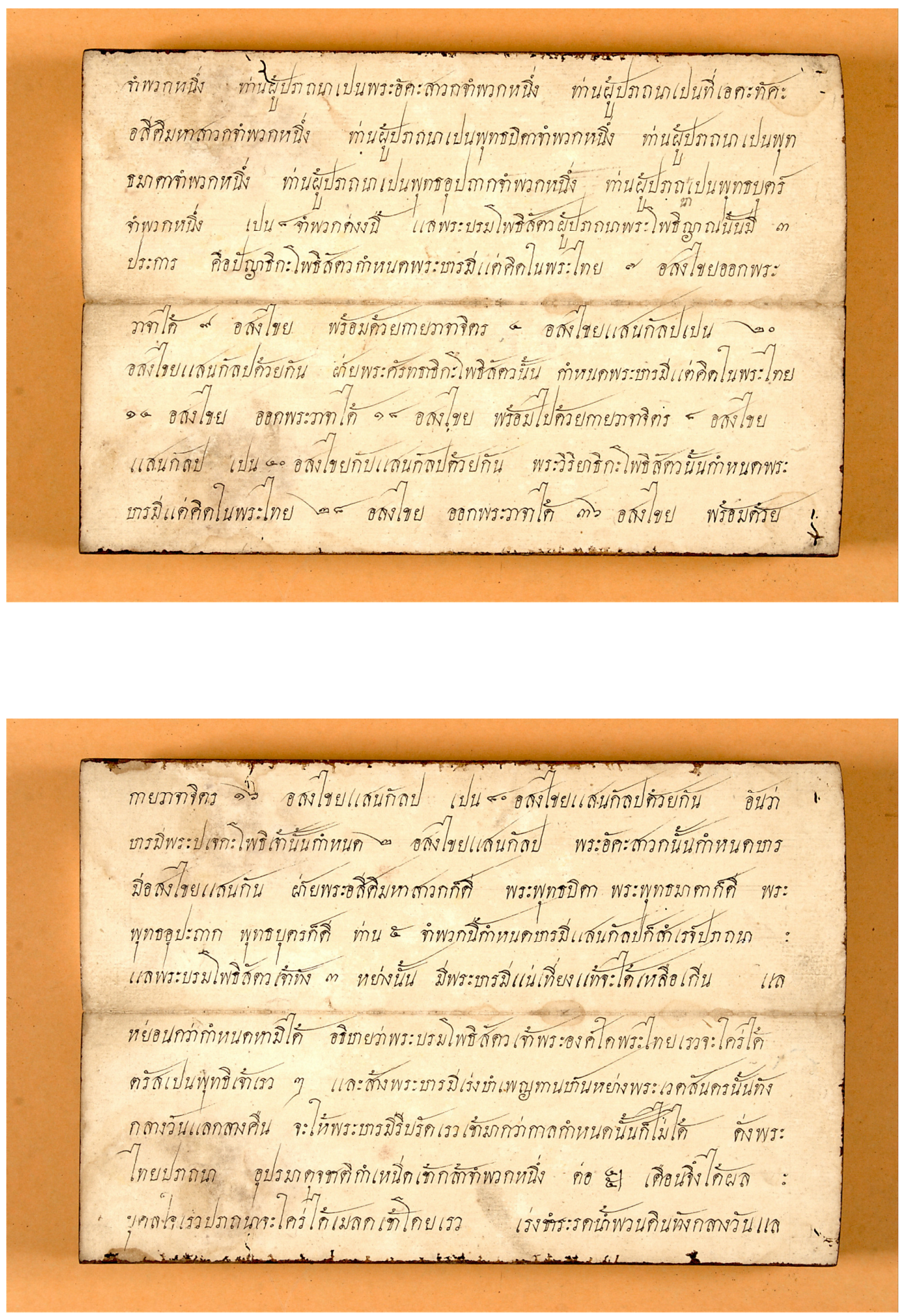